\title{
BEE-ING CHINESE IN SOUTH AFRICA: A LEGAL HISTORIC PERSPECTIVE
}

\author{
Karen L Harris*
}

\section{ABSTRACT}

This article traces the history and dilemma of the South African born Chinese (SABCs, also known as the indigenous Chinese) in terms of their legal dispensation. Within months of the implementation of the Broad-Based Black Economic Empowerment Act 35 of 2003, it became apparent that the Chinese communities were excluded as beneficiaries of the legislation as well as from the Employment Equity Act 55 of 1998. This situation was in line with the treatment that the Chinese had received since they first arrived in the Cape Colony towards the end of the seventeenth century, and was perpetuated throughout the subsequent centuries to beyond the 1994 new political dispensation. The exclusion of the Chinese from Broad-Based Black Economic Empowerment and Employment Equity and their legal action challenging the Acts, took place against the backdrop of stereotypical representation in popular consciousness and ignorance of a people who have been part of the South African past for three centuries. This article places the South African Chinese legal battle of the twenty-first century within the context of their perpetual invidious position in South Africa's past. It traces the neglected and checkered legal history of a marginalised minority.

* Professor, Head of Department of Historical and Heritage Studies; Director, University of Pretoria Archives; University of Pretoria. 
Keywords: Chinese South Africans; Employment Equity Act; Broad-Based Black Economic Empowerment Act; discrimination; apartheid; segregation; Dignity Day

\section{Introduction}

In the year 2008 the South African High Court in Pretoria ruled that the South African Chinese community were "black" in terms of Employment Equity and Broad-Based Black Economic Empowerment. This was the result of an eight-year battle launched by the Chinese Association of South Africa to clarify their status in terms of affirmative action and empowerment legislation. In this instance they took recourse to their history and place in the South African past. The case was eventually unopposed by the Respondents, yet while the court decision heralded an important milestone victory, the subsequent media, public and ministerial reaction cast a shadow over their successful plea. This article will trace the position of the Chinese in terms of the court case, as well as their history, indicating how they had been legally discriminated against since their arrival in southern Africa some three centuries ago. It will consider the situation that preempted the case, the plan of action, the court case and the invidious situation that ensued.

\section{Status quo}

Since 1994, in an attempt to create a more equitable South African society within the newly-found democracy, various pieces of legislation were drafted to redress the inequalities of the past. Two key pieces of legislation that were promulgated were Act 55 of 1998, the Employment Equity Act, ${ }^{1}$ followed five years later by Act 53 of 2003, the Broad-Based Black Economic Empowerment Act. ${ }^{2}$ In short, the combined effect was "to promote equity and fairness in the labour market and in trade and

1 Employment Equity Act no 55 of 1998 . The point of this legislation is to strive to attain equity in the workplace by promoting fair treatment and equal opportunity through the elimination of unfair discrimination and by the implementation of affirmative action measures so as to redress the disadvantages in employment experienced by designated groups. See https://www.saica.co.za/ Technical/LegalandGovernance/Legislation/EmploymentEquityAct/tabid/3041/language/en-ZA/ Default.aspx.

2 Broad-Based Black Economic Empowerment Act no 53 of 2003. This subsequent legislation aims to "ensure that the economy is structured and transformed to enable the meaningful participation of the majority of its citizens and to further create capacity within the broader economic landscape at all levels through skills development, employment equity, socio economic development, preferential procurement, enterprise development, especially small and medium enterprises, promoting the entry of black entrepreneurs into the mainstream of economic activity, and the advancement of co-operatives. B-BBEE needs to be implemented in an effective and sustainable manner in order to unleash and harness the full potential of black people and to foster the objectives of a pro-employment developmental growth path". See http://www.edd.gov.za/aboutus/programmes/economic-policy-development/b-bbee. 
industry". ${ }^{3}$ Also, "against a background of apartheid and discriminatory laws" to give those members of society that had been discriminated against access to employment opportunities and employment equity, to ensure workforce diversity, promotion of economic development and access to financial deals and other forms of assistance in the corporate and business environment, while establishing a legislative framework for the management and monitoring of black economic empowerment. ${ }^{4}$

According to the definitions of the Employment Equity legislation, the Act applied to "black people" which was defined as "a generic term which means Africans, Coloureds and Indians". 5 Thus having been excluded from the benefits referred to in the Employment Equity legislation under apartheid and having been classified as "coloured" by the Population Registration Act in $1950,{ }^{6}$ it was believed by the Chinese community that they should be included in the application of the legislation. However, by the end of the 1990s, it became increasingly apparent to members of the South African Chinese community that they were being discriminated against in terms of employment equity, as well as matters relating to preferential shares and other economic empowerment deals in both the public and private sectors. ${ }^{7}$

In the Eastern Cape Province, for example, a Chinese businesswoman submitted an application to open a business in a casino complex. She was informed that according to the Employment Equity Act, "30 per cent of the businesses in the complex had to be black owned" and as the "newly implemented Employment Equity Act [did] not regard Chinese people as previously disadvantaged" she would probably not qualify. ${ }^{8}$ A member of the corporate world added that in terms of the Act "black" meant "African, Coloured and Indian and that Chinese people did not count". ${ }^{9}$ Another example involved a Chinese employee who had worked in the IT division of a bank for some twenty-five years. When the bank launched the first

3 Chong 2007: 4.

4 Annual Survey of South African Law 1998, Employment Equity Act no 55 of 1998, School of Law, University of the Witwatersrand 2004 567; Annual Survey of South African Law 2003, BroadBased Black Economic Empowerment Act no 53 of 2003, University of the Witwatersrand 2004 494.

5 Employment Equity Act ch 16 Act 55 of 1998 .

6 Population Registration Act no 30 of 1950. Initially the Act identified three groups: "white", "black" and "coloured". While the latter group was intended to be more inclusive to accommodate people who were not members of the other two groups there was widespread reaction. This led to Proclamation no 73 of March 1951 whereby three "new" groups - Indian, Chinese and Malay were identified as sub-divisions of the "coloured group". See Harris 1999: 187-188.

7 The Chinese Association - Gauteng: Newsletters, Aug 2000, Jun, Jul, Aug 2002. Discussions and meetings were held within the Chinese communities across the country regarding the apparent discrimination. Already in 2000 it was claimed that the "Chinese were being marginalized" and it was decided that CASA should "approach the problem at national level". See Anon 2004: 10; Sakato 2005: 6; Ford 2006: 24; and Terblanche 2006: 10.

8 Adkins 2000: 7; Anon 2000: 4. Ah Hing was an owner of a sweetshop in Port Elizabeth and had put in a tender to open a fudge shop in the new Summerstrand casino complex.

9 Sundstrom \& Van der Merwe 2000: 10. 
phase of its empowerment share offer his application was refused on the grounds that the finance sector of the Charter Council had advised that the definition "excludes people of Chinese origin". ${ }^{10}$ The same response was made when the second phase of the scheme was launched. ${ }^{11}$ To further confuse matters, two other banking institutions subsequently announced that South African Chinese would be included in their empowerment share schemes. ${ }^{12} \mathrm{~A}$ third example related to a municipal affirmative action land sales policy which attempted to give those from "former disadvantaged communities an opportunity to own land by giving them favourable concessions to acquire the land". ${ }^{13}$ According to this, only South African citizens from "designated groups" - as defined in the Employment Equity Act - could buy sites identified for sales in terms of the policy. Here again the Chinese were excluded. ${ }^{14}$ Lastly, in the recruitment for affirmative action positions, Chinese applicants were turned down as "according to South African AA standards ... only black, coloured and Indian need apply". ${ }^{15}$

On challenging the situation, the government reaction at local, provincial and national level remained vague and inconsistent. A spokesperson of the Department of Labour commented that the African National Congress did not view the Chinese "among previously disadvantaged groups" because they were "a small group with no voice". ${ }^{16}$ In another instance, an African National Congress councillor stated that the party was aware that the Chinese had suffered, but what was to be considered most was "the degree of suffering". ${ }^{17}$ Nerine Kahn, Chief Director of Labour Relations in the Department of Labour, claimed that "the Chinese had been very irritating because they believe it would be that simple to make an amendment" to the Employment Equity Act and Broad-Based Black Economic Empowerment legislation. ${ }^{18}$ Government officials also claimed that "the history of Chinese South Africans [was] far too complex to allow them to make a decision about where they stand now". ${ }^{19}$

10 Anon 2006: 10. The bank claimed that the Charter Council had advised that this definition (in the Employment Equity Act and the Broad Based BEE Act) excludes people of Chinese origin.

11 Anon 2006: 10; Whyte 2005a: 11.

12 Rossouw 2005: 20; Jacks 2005: 69; Cameron 2005: 35. Standard Bank introduced two empowerment share schemes: the Tutuwa Scheme and the Share Scheme, but excluded the Chinese as beneficiaries. Other banks, such as Old Mutual, Nedbank and ABSA, did not exclude Chinese from such schemes.

13 Mativire 2000: 6.

14 Idem 4. Again it was the Port Elizabeth City Council that refused the application which was made to its town planning and land use committee.

15 Holmes 2000: 4. This was a Nedcor IT training program for affirmative action candidates.

16 Anon 2000: 4; Adkins 2000: 7.

17 Matavire 2000: 4. This would be an ongoing debate and point of contention and was to resurface after the court case was won by CASA in Jun 2008, particularly among politicians and the media which again reflected on the uninformed nature of the broader populace regarding the history of the Chinese in South Africa.

18 Sakato 2005: 6.

19 Ibid. 
Lionel October, Deputy Director General of the Department of Trade and Industry, which drives the policy, ${ }^{20}$ insisted that "the thrust of Broad-Based Black Economic Empowerment was to correct the inequities of people commonly understood as African, Indian and coloured". Both his Department and that of Labour argued that

the Chinese were never discriminated against consistently. The departments would have to assess how they were discriminated against, if the discrimination was sustained, and if it equaled the discrimination faced by other "blacks". ${ }^{21}$

October stated that the Chinese concerns had to be "put on hold indefinitely while legal opinions [were] formed and other political and economic stakeholders [were] consulted". ${ }^{22}$ In 2007, the matter was still being debated and various government divisions and private sectors persisted in pronouncing that the Chinese should not be considered as part of Employment Equity or Broad-Based Black Economic Empowerment benefits. ${ }^{23}$

While this uncertainty continued, Cliffe Dekker Attorneys, who had published a widely acknowledged guidebook to black economic empowerment in South Africa, had in fact already prepared a report on the matter for EmpowerDEX and the Department of Trade and Industry in 2004. The nine-page report concluded that it was Cliffe Dekker Attorneys' considered view that

the breadth of discriminatory legislation applicable to Chinese people in South Africa between 1984 and 1993 is such that any suggestion that they should not qualify as being "Black people", "historically disadvantaged South Africans" or "historically disadvantaged individuals" would patently [be] unfair and, quite possibly, unfairly discriminatory as contemplated in section 9 of the Constitution of the Republic of South Africa Act. ${ }^{24}$

20 Annual Survey of South African Law 2003, Broad-Based Black Economic Empowerment, School of Law, University of the Witwatersrand 2004494.

21 Sakato 2005: 6.

22 Ibid. CASA argued that this so-called confusion arose as a result of people not understanding the community's history which was "causing an inconsistent interpretation of current affirmative action laws". CASA maintained that the Chinese were "historically disadvantaged in terms of the Race Classifications Act of 1956".

23 Anon 2007.

24 Cliffe Dekker Incorporated "The status of South Africans of Chinese descent", Prepared for Empowerdex and the Department of Trade and Industry 2004 9. According to sec 9 of the Constitution: (1) Everyone is equal before the law and has the right to equal protection and benefit of the law. (2) Equality includes the full and equal enjoyment of all rights and freedoms. To promote the achievement of equality, legislative and other measures designed to protect or advance persons, or categories of persons, disadvantaged by unfair discrimination may be taken. (3) The state may not unfairly discriminate directly or indirectly against anyone on one or more grounds, including race, gender, sex, pregnancy, marital status, ethnic or social origin, colour, sexual orientation, age, disability, religion, conscience, belief, culture, language and birth. (4) No person may unfairly discriminate directly or indirectly against anyone on one or more grounds in terms of subsection (3). National legislation must be enacted to prevent or prohibit unfair discrimination. (5) Discrimination on one or more of the grounds listed in subsection (3) is unfair unless it is established that the discrimination is fair. 
Yet, despite this report, the Chinese continued to remain outside of the ambit of the two Acts, while uncertainty among the Chinese community, as well as business and government sectors, persisted.

The Chinese community argued that the application of the Acts left them "vulnerable to the same discrimination they suffered under apartheid" and failed to "recognize Chinese South Africans' status as people who were disadvantaged by previous governments". ${ }^{25}$ It was felt that under the apartheid government they were "not white enough" and now under the new government they were "not black enough". ${ }^{26}$ They regarded this as a "double jeopardy" and questioned whether it was "not unfair to punish a minority twice for a crime they did not commit". ${ }^{27}$ The change from white minority rule to black majority rule had left them in the "same no-man's land they had always occupied in this country" ${ }^{28}$ making them the "classic victims of reversed racism". 29

\section{Modus operandi}

These Employment Equity and Broad-Based Black Economic Empowerment concerns of the Chinese community that were sporadically voiced in the media were eventually channeled to their local associations and ultimately their national organisation, the Chinese Association of South Africa. It is important to point out that the South African Chinese, not unlike their overseas Chinese (haiwa huaren) counterparts the world over, had generally opted to maintain a low political profile..$^{30}$ The Chinese Association of South Africa was actually only founded in March 1981 in reaction to a political dilemma that was foisted upon them by the apartheid government. In an attempt to appear more "politically inclusive", the National Party government had introduced a sixty-member President's Council appointed from the "white, coloured, Indian and Chinese population groups" to act as a consultative body to advise the government. The Chinese refused to accept participation on the grounds that "their numbers did not warrant participation" nor did they believe

25 Accone 1998: 12; Sundstrom \& Van der Merwe 2000: 10.

26 Nwajah 2000: 16.

27 Whyte 2005b: 14. While the Chinese had been discriminated against under the apartheid government they were also discriminated against under the new democratic government. However, this discrimination against them as an identifiable cultural group reaches as far back as the early twentieth century with the introduction of the Chinese Exclusion Act in 1904 and, one could argue, to the seventeenth century under the Dutch East India Company rule when they were disallowed certain economic rights.

28 Robins 1997: 8.

29 Nwajah 2000: 16. According to MYap (co-author of Colour Confusion and Concession) "[i]n the past they were not regarded light enough to be white, now they are not dark enough to be black".

30 Anon 1981: 6; Wilkins 1981: 31. The overseas Chinese in countries such as the United States of America, Australia and New Zealand generally opted to maintain a low profile in terms of politics within their host countries. 
they had the "right to make decisions affecting much larger population groups" and that they "preferred no role until full rights [were] given". ${ }^{31}$ Instead they decided to unite the existing six disparate Chinese regional organisations into one umbrella organisation as this would then enable them to articulate their position and demands with one voice. ${ }^{32}$ One of the main mission statements of the Chinese Association of South Africa's reads as follows:

We are dedicated to promoting and preserving the Chinese cultural identity and heritage, and safeguarding the interests of Chinese in South Africa. ${ }^{33}$

In May 2000 the Chinese Association of South Africa chairperson wrote to the Minister of Home Affairs to attain clarity as to the classification of Chinese people. This was followed over the next five years by the Chinese Association of South Africa making submissions to the Director of Equal Opportunities, the Labour Portfolio Committee and the Departments of Labour, Trade and Industry, but all in vain..$^{34}$ At the end of 2004 in a response to a question in the National Council of Provinces whether Chinese employees must be classified as "coloureds" for the purposes of submissions in terms of the Employment Equity Act, the Minister of Labour stated as follows:

[O]n whether the Chinese are included or excluded from the definition of designated groups or are being unfairly discriminated against in terms of The Employment Equity Act, individuals or groups have the right to seek clarity or legal recourse via the Courts. ${ }^{35}$

And again the Department of Trade and Industry and the Financial Sector Charter Council reiterated this view that

[t]he department is absolutely clear that the definition of "black people" as contained in the latest draft of the codes will stand. This excludes the classification of Chinese people as "black" for purposes of broad-based black economic empowerment. ${ }^{36}$

This stance, and the fact that the Chinese Association of South Africa had as yet not received any formal responses to its various submissions to government since 2000, left the Chinese community with no other option than to take legal action and recourse

Anon 1980: 8.

32 Anon 1981: 6.

33 CASA Mission Statement: 2004. CASA was established as a "voluntary and non-profit national community organisation which promotes the interests of the Chinese community in South Africa". According to clause 22 of the Constitution the Association is a "corporate body under common law, with perpetual succession and shall sue and be sued in its own name".

34 Chinese Association of South Africa v Minister of Labour (59251/2007) [2008] ZAGPHC 174 (18 Jun 2008) "Chinese Association of South Africa: chronological timeline" 2008 1-2.

35 Idem 2.

36 Whyte 2005b: 14. 
to the courts. ${ }^{37}$ The Cape Town-based attorneys Edward Nathan and Sonnenbergs were assigned the case and, should it go to court, human rights advocate George Bizos and constitutional law advocate Alfred Cockrell were appointed to appear. ${ }^{38}$ In June 2006 Edward Nathan and Sonnenbergs addressed letters to the Ministers in the Departments of Labour, Trade and Industry and Justice and Constitutional Development regarding the matter. These formal letters of demand state as follows:

We invite you and the two other concerned Ministers to indicate whether or not you agree with our clients' view that Chinese people should be regarded as "Coloured" and, accordingly, fall within the ambit of the phrase "black people" as used in The Employment Equity Act and The Broad-Based Black Economic Empowerment Act. ${ }^{39}$

At the end of June 2006 the Department of Labour responded to a query by Accenture SA (Pty) Ltd regarding the status of the Chinese in terms of Employment Equity. They stated that "individuals of Chinese descent are not designated and should not be included in the Employment Equity Report as a sub-group of Coloureds". They continue "to confirm that Chinese individuals should be reflected as 'white' in terms of employment equity, especially if they are citizens of this country"..$^{40}$ As a result, in December 2007 the Chinese Association of South Africa launched an application in the Pretoria High Court against three ministerial departments: the Minister of Labour, the Minister of Trade and Industry and the Minister of Justice and Constitutional Development. A month later all three Respondents filed a notice to oppose, but Justice and Constitutional Development as the third Respondent ultimately indicated that they "would not oppose the Notice of Motion but would abide by the court's decision". ${ }^{41}$

\section{$4 \quad$ Locus standi in iudicio}

The attorneys Edward Nathan and Sonnenbergs compiled a Notice of Motion whereby the three Applicants, namely the Chinese Association of South Africa, Victor Chong and Albert Peter Fung, applied for an order in which Prayer 1 read as follows:

37 Sakato 2005: 6.

38 Terblanche 2006: 10. ENSafrica is Africa's largest law firm boasting one hundred years of experience. George Bizos is a Human Rights lawyer of note who had campaigned against apartheid and also represented Nelson Mandela in the Rivonia Trial. Alfred Cockrell SC is a former professor of law at the University of the Witwatersrand. George van Niekerk of Edward Nathan and Sonnenbergs in Cape Town was appointed to act for CASA.

39 Chinese Association of South Africa v Minister of Labour (59251/2007) [2008] ZAGPHC 174 (18 Jun 2008) "Chinese Association of South Africa: chronological timeline" 2008: 2-3.

40 Idem 3. Accenture SA (Pty) Ltd which is a global management consulting, technology services and outsourcing company.

41 "Chinese Association of South Africa: chronological timeline" 2008: 3. 
that the South African Chinese people:

(a) fall within the ambit of the definition of "black people" in section 1 of the Employment Equity Act 55 of 1998;

(b) fall within the ambit of the definition of "black people" in section 1 of the Broad-Based Black Economic Empowerment Act 53 of 2003. ${ }^{42}$

Failing the above, the alternative Prayer requested that the definition of "black people" in both Acts be declared "inconsistent with the Constitution and invalid by virtue of its failure to include Chinese people within its ambit". This then would require the addition of the phrase "and Chinese people" at the end of the current definition of "black people" in both Acts. In addition, Prayers 3 and 4 referred to the payment of the costs of the application "on a joint and several basis". ${ }^{43}$

In the overview of the application it was pointed out that "during the apartheid era South African Chinese people were regarded as 'coloureds' under numerous apartheid laws which divided the population into various groups". As a result, the South African Chinese were "treated as second-class citizens and derived no better treatment from the law than other racial or ethnic groups regarded as 'coloured' or non-white". Besides the explanations dealing with the Applicants and the "declaratory order" they sought, the application also set out a well-researched summary of the "manner in which Chinese people were treated before 1994". ${ }^{4}$

The discriminatory regulations that South African Chinese were subjected to were outlined in the "legislative framework" of the Application. All relevant pieces of apartheid legislation which impacted on the Chinese were briefly discussed. Starting with the Population Registration Act of $1950,{ }^{45}$ the "negative criteria" that were used to define the classification of the South African Chinese as "coloured" were pointed to. The Chinese fell within this group only because they were not "whites" or "natives". In point of fact, within a year of its promulgation the legislation was amended to sub-divide the "coloured group" into three additional groups: Indian, Chinese and Malay. ${ }^{46}$ By Proclamation no 46 of 1959 the "coloured" category was again subdivided into seven different "coloured" groups, which again designated a "Chinese group". ${ }^{47}$ The imprecision and unwieldiness of the Act is evident in the fact

$42 \quad$ Idem at 2.

43 Idem at 2-3.

44 Idem at 3. This first applicant's founding affidavit comprised 351 pages and included an 84-page account of the legislative structure that discriminated against the Chinese. It also included 164 pages regarding discrimination against the Chinese from the book by Melanie Yap and Diane Man, Colour, Confusion and Concessions.

45 Statutes of the Union, Population Registration Act 30 of 1950. This Act was only repealed in Jun 1991. It is, however, maintained that the racial categories devised in the 1950 Act persist in South African society such as the census as well as the legislation introduced to remedy the inequalities of the past.

46 Proclamation no 73 Mar 1951.

47 Proclamation no 46 Mar 1959. 
that it was amended eight times before it was eventually repealed four decades later. The application emphasised that as such, discrimination against the South African Chinese was "widespread and systematic" throughout the apartheid years. The eight areas used to substantiate this claim were education; employment; ownership of property; trading/business rights; voting rights; separate amenities; freedom of movement; and marriage. ${ }^{48} \mathrm{~A}$ detailed eighty-four page memorandum analysing this discriminatory legislation was also submitted, along with numerous extracts from the book Colour, Confusion and Concessions: The History of the Chinese in South Africa authored by Melanie Yap and Dianne Leong Man. ${ }^{49}$

The court application also included affidavits from six other individuals that included members from both within and outside of the Chinese community. In the second applicant's affidavit, Victor Chong recounts his career as a "non-white" social worker, trader and later teacher at a "coloured" school. The discrimination he endured included - amongst others - permits to study, to trade and to reside as well as the fact that he earned a salary a third less then his white counterparts with the same qualifications. He was also denied shares in the Johannesburg Stock Exchange Black Shareholder retention Scheme..$^{50}$ The third applicant, Albert Peter Fung, mainly focused his affidavit on his exclusion from his company's Black Ownership initiative even though he was treated as a "non-white" and had worked for them for over twenty years. ${ }^{51}$ The evidence of Leslie Hum Hoy, who qualified as an architect, stated that he had to leave the country as although he was offered a partnership in a firm, his "non-white" status resulted in him being refused this on legal grounds. He furthermore recounted how he was also asked to leave hotels and other public amenities where he met clients because of his Chinese "non-white" status. ${ }^{52}$ The next two affidavits were primarily concerned with the history of the Chinese in this country. Authors Melanie Yap and Dianne Leong Man verified the methodology and research of their abovementioned book. ${ }^{53}$ Lastly, there was an affidavit that focused

48 Chinese Association of South Africa v Minister of Labour (59251/2007) [2008] ZAGPHC 174 (18 Jun 2008) Notice of Motion: case no 59251/07 High Court of South Africa (TPD) Legislative Structure: Discrimination, Pretoria 18 Jun 2008: 1-84.

49 Yap \& Man 1996. See the review articles on this book by Harris 2009: 116-128 and Harris 1997: 316-325.

50 Chinese Association of South Africa v Minister of Labour (59251/2007) [2008] ZAGPHC 174 (18 Jun 2008) Second Applicant's founding affidavit: V Chong pp 1-17 case no 59251/07 High Court of South Africa (TPD) Pretoria 18 Jun 2008.

51 Chinese Association of South Africa v Minister of Labour (59251/2007) [2008] ZAGPHC 174 (18 Jun 2008) Second Applicant's founding affidavit: AP Fung, pp 1-12 case no 59251/07 High Court of South Africa (TPD) Pretoria 18 Jun 2008.

52 Chinese Association of South Africa v Minister of Labour (59251/2007) [2008] ZAGPHC 174 (18 Jun 2008) Second Applicant's founding affidavit: LH Hoy, pp 1-9 case no 59251/07 High Court of South Africa (TPD) Pretoria 18 Jun 2008.

53 Chinese Association of South Africa v Minister of Labour (59251/2007) [2008] ZAGPHC 174 (18 Jun 2008) Second Applicant's founding affidavit: Yap 1-12 and DL Man 1-5 case no 59251/07 High Court of South Africa (TPD) Pretoria 18 Jun 2008. 
on an assessment of Colour, Confusion and Concessions as a reliable text,,${ }^{54}$ as well as a select historical overview of discrimination against the Chinese from the very first stages of colonialism, and the position of the Chinese community under apartheid and the post-apartheid period. ${ }^{55}$

That discrimination against the Chinese was rife is indeed evident in the historical record and dates back to the first arrivals at the Cape. To begin with, in the early eighteenth century the Dutch East India Company (DEIC) introduced plakkaten (ordinances) in, for example, 1727 and 1740 that forbade the miniscule Chinese community certain trading rights in the Cape region. ${ }^{56}$ Many of these legal regulations were introduced to address the protests by certain Dutch burgers that could apparently not compete against the "industrious" Chinese and appeared to have a kind of disdain for them. ${ }^{57}$ They were, for example, not to sell baked goods or fresh fruit and vegetables in the streets with a transgression leading to confiscation of the produce and fines. They were also relegated to living areas on the outskirts of Cape Town and had a separate burial ground. Moreover it was declared they were not to wear Western clothes so that they could be easily identified. ${ }^{58}$

In the nineteenth century independent Boer Republics ${ }^{59}$ introduced legislation that restricted the presence and movement of Asians. Although the number of Chinese remained very small and the legislation was more often than not directed at Indians,${ }^{60}$ the Chinese fell within the ambit of this legislation and were also subjected

54 Harris 1997: 316-325.

55 Chinese Association of South Africa v Minister of Labour (59251/2007) [2008] ZAGPHC 174 (18 Jun 2008) Second Applicant's founding affidavit: Harris 1-12 case no 59251/07 High Court of South Africa (TPD) Pretoria 18 Jun 2008.

56 Armstrong 1997: 36-37; Jeffries \& Naude: 121 . There were no more than about 150 Chinese at the Cape during the Dutch East India Company period (1652-1799). However, regardless of the miniscule numbers they were identified and discriminated against in terms of their economic and social activities.

57 Harris 2010: 223-224. Almost a century and a half later a similar situation arose when Europeans on the Witwatersrand objected to the apparent competition the Chinese traders posed. They declared that these Chinese merchants were causing them "a great injury and were a serious menace". The Indian Opinion, most probably Mahatma Gandhi, wryly commented that "if the Chinese shopkeepers [were] allowed to supply the necessities to their countrymen, it would be the height of injustice and deprivation of the rights of the European shopkeepers", adding that they confessed their "utter inability to compete with the Chinese". See Harris 1995: 162-163 for a detailed discussion of this perpetuated idea of a perceived economic threat.

58 Jeffries \& Naude 1948: 121.

59 Two independent Boer Republics were established in the interior of southern Africa in 1852 and 1854 as a result of two conventions signed between the British colonial government and the Boer leaders: Zuid-Afrikaansche Republiek and the Oranje Vrystaat. There were two other states under the British colonial government, namely the Cape and Natal colonies.

60 While Indians had been present at the Cape as part of the enslaved community since the latter quarter of the seventeenth century, the introduction of 152184 indentured Indians into the Natal Colony to work on the sugar plantations in the mid-nineteenth century had heightened an awareness and resistance against them. See Harris 2010c: 147. 
to the restrictions. In the Zuid Afrikaanse Republiek, Law 3 of 1885 required that all "persons belonging to the native races of Asia" register and carry annually renewable passes. ${ }^{61}$ In 1893 this regulation was extended by a resolution whereby every Chinese had to obtain an annual special pass with a stamp to the value of twenty five pounds. ${ }^{62}$ It also denied them the right to ownership of property except in government designated "streets, wards and locations". ${ }^{63}$ In the other Boer Republic, the Orange Free State, legislation was introduced in 1891 which forbade "Chinese coolies or other Asiatic coloureds" from settling or remaining in the territory ${ }^{64}$ This particular piece of legislation remained on the statute books for close on a century, only being repealed in $1986 .{ }^{65}$

In the early twentieth century, under British colonial rule, the Chinese were subjected to one of the first overtly racist pieces of legislation introduced during the genesis of white hegemony in southern Africa, namely the Chinese Exclusion Act of 1904. ${ }^{66}$ This legislation required that all Chinese residents in the Cape Colony had to apply for a permit (a Certificate of Exemption). In addition they had to register with the district magistrate, notify and re-register with the authorities if they moved, and apply to renew the permit annually. ${ }^{67}$ This discriminatory Act of 1904 remained on the statute books until 1933 and had the "restrictive efficiency" of halving the number of Chinese in South Africa and essentially ending the immigration of Chinese for the remainder of the century. ${ }^{68}$ In the Transvaal Colony the Chinese fared little better. Here legislation that also applied to the Indians required them to register,

61 Codex van Den Locale Wetten ZAR Wet no 31885.

62 De Locale Wetten en Volksraad Besluiten der ZAR Art 13531893.

63 Statute Laws of the Transvaal Law no 3 Jun 1885: 135.

64 Wetboek van die Oranjevrijstaat 1891 Hoofdstuk xxxiii.

65 Statutes of the Republic of South Africa, Matters Concerning Admission to and Residence in the Republic Amendment Act 53 of 1986.

66 Statutes of the Cape of Good Hope 1902-1906, The Chinese Exclusion Act 37 of 1904. It is important to note that Exclusion Acts had been implemented against the Chinese in other colonial destinations prior to the implementation in the Cape Colony: Australia in 1851, New Zealand in 1881, the United States of America in 1882 and Canada in 1885. The 1904 Act has been relatively ignored in South African history mainly because it does not accord with the black-white dichotomy of traditional historical analysis.

67 Statutes of the Cape of Good Hope 1902-1906, The Chinese Exclusion Act 37 of 1904. Following in the wake of the "Immigration Act of 1902", the restrictive nature of the Exclusion Act revealed the not-so-liberal and racist underside of Cape colonial politics. At the time of the promulgation of the Act, the proposers declared that they had drafted the legislation in "as radical a manner as possible, but welcomed any amendments or provisions that would make it more so". They had apparently followed the example of Australia and the United States of America by dealing separately with Chinese immigration, rather than combining it with the Alien Immigration Law. The rationale was that these other countries had found that "the Chinese as a race could be more easily dealt with than any other race that came under the Alien Immigration Laws". For further discussion of this see Harris 1998a: ch 5.

68 Statutes of the Union of South Africa, The Immigration Amendment Act no 191933. 
obtain passes and be fingerprinted. The "Black Act" of 1907 against which Mahatma Gandhi protested was thus equally applicable to the small Chinese community, and was likewise objected to by them. ${ }^{69}$

Moving into the twentieth century, under the apartheid regime, from the outset the Chinese were classified as "non-white". As indicated above, in 1951 they formed a sub-group of the "coloured group" and remained as such without the vote until 1994. ${ }^{70}$ They were therefore subjected to all the disadvantages of people who were not white. Their small size and low political profile often propelled them into extremely tenuous situations. For example, for two decades the apartheid architects tried to allocate Chinese group areas, but except for Kabega Park in Port Elizabeth, their numbers did not warrant an area. Instead, they were subjected to a permit system whereby they had to apply for permission from the Department of Community Development and obtain a "no objection" from immediate neighbours before moving into an area. They were also affected by the resultant Group Area forced removals and clearing of "mixed" areas which often left them displaced and destitute. ${ }^{71}$ Permit and permission permeated all dimensions of their lives ${ }^{72}$ until 1994 when they supposedly became part of the new non-racial democratic South Africa.

It thus becomes clear that the exclusion of the Chinese from the benefits of the two Acts (Employment Equity and Broad-Based Black Economic Empowerment) was not something new to them - before and during the apartheid period they had endured similar discriminatory treatment. They were yet again in the extraordinary predicament of being in an "interstitial position". ${ }^{73}$ The merits of the case were, however, of such a nature that although all three Respondents had initially filed a notice to oppose, by April 2008 "they eventually conceded" 74 and the State Attorney indicated that "the Respondents consent to prayer 1 of the Notice of Motion and that

69 Statutes of the Transvaal 1907, Asiatic Law Amendment Act 2 of 1907. This legislation was introduced by the Transvaal legislature to specifically curb the influx of Indians into the colony, but applied to all "Asiatics", including the Chinese. Not unlike the Cape Colony legislation that preceded it, it required the compulsory registration of all Asians with a Registrar and a certificate of registration with information such as name, residence, age, caste, marks of identification as well as finger and thumb impressions. The penalty for failing to comply ranged from a fine to imprisonment and deportation. Although there had been legislation in both the Zuid-Afrikaanse Republic and the Transvaal Colony restraining and regulating the Asian communities prior to this, the implications of this legislation were far more restrictive than any previous legislation and thus resulted in the protest reaction that ensued. See Harris 1998a: ch 6.

70 Proclamation 46 of 1959.

71 Harris 1999.

72 Besides the Population Registration and Group Areas Acts, the Chinese were to find themselves in an invidious position in terms of public amenities such as access to hospitals, public transport, cinemas, beaches, fishing areas as well as education. For the most part they were relegated to the non-European facilities, while at times they were treated as coloured or could be designated facilities specifically allocated for Chinese. See Yap \& Man 1996: ch 11.

73 Harris 1998b.

74 SAPA 2008: 5. 
the matter may be set-down on an unopposed basis". ${ }^{75}$ The Respondents, however, indicated that they would not accept liability for the costs, but after the attorney's intervention, this too was conceded. On 18 June 2008 in the High Court in Pretoria at 10:00, Judge Cynthia Pretorius ruled that in case number 59251/07 the South African Chinese "fall within the definition of black people in the Constitution", allowing them to "now enjoy the full benefits of black economic empowerment". ${ }^{76}$

For the Chinese it was more than being acknowledged for Broad-Based Black Economic Empowerment. According to Patrick Chong, chairman of the Chinese Association of South Africa, the Chinese community's struggle had "not been about economic opportunism, but about lack of recognition and clearing up of the misconceptions of the historical injustices the South African Chinese faced". He said that the court decision "recognized the need for human dignity for the Chinese people, who didn't fit in under apartheid ... or after 1994". "The Chinese community celebrated the court ruling by hosting an event they called "Dignity Day", underlining that this was indeed a case of rectifying their place in South Africa's past. ${ }^{78}$

\section{Post hoc ergo propter hoc}

While members of the Chinese community were visibly overjoyed, some even overwhelmed, by the decision after their eight-year legal battle with government, ${ }^{79}$ the euphoria was short-lived. The local and international media had a field day with headlines such as "Chinese locals are Black"; 80 "Chinese not black"; 81 "Race makes nations act funny"; and "In South Africa, Chinese is the New Black", ${ }^{82}$ while cartoons caricatured the stereotypical Chinese with captions like "Chinese nou ere-swartes" ("Chinese now honorary blacks"). ${ }^{83}$ More disturbing were the reactions and responses from certain sectors of the public and government ${ }^{84}$ but in particular, comments by the First Respondent in the case Minister of Labour, Membathisi Mdladlana. ${ }^{85}$ It

75 Chinese Association of South Africa v Minister of Labour (59251/2007) [2008] ZAGPHC 174 (18 Jun 2008) "Chinese Association of South Africa: chronological timeline" 2008: 3.

76 SAPA 2008: 4; Fourie 2008: 6; Masombuka 2008: 4.

77 Ho 2008: 1; Gerardy 2008: 8.

78 See Harris 2010: 147-162. Dignity Day was celebrated by the community for the following five years. Celebrations were held by the various regional associations with speakers reminiscing on past experiences.

79 Fourie 2008: 6.

80 Ho 2008: 1.

81 Ndlovu 2008: 4.

82 Accone \& Mthethwa 2008:13.

83 Cartoon 2008a: 18; Cartoon 2008b: 12. This was the type of media attention that the Chinese had traditionally tried to avoid. It also reflected on the embedded stereotyping of the Chinese in popular consciousness - a phenomenon that resonated with depictions of the Chinese in other overseas destinations.

84 Ndlovu 2008: 4; MacKenzie 2008: 20; Rossouw 2008: 6.

85 SAPA 2008a: 2; Ngqiyaza 2008a: 3. Mdladlana was appointed Minister of Labour in 1998 and held the position until 2010. 
turned out, as journalist Mohau Pheko aptly summed up: "Black judgment subjects Chinese to animosity, not equality" 86 as once again the small South African born Chinese community were thrust into the unwanted spotlight with much conjecture about their status being bandied around. ${ }^{87}$

The Labour Minister's controversial comments were made at a media briefing where he reportedly stated the following:

Now that they had been classified coloured, Chinese employers had no excuse to mistreat workers or pretend to labour inspectors that they could not speak a South African language ... What I know is that coloureds don't speak Chinese.

He also said that

the Chinese might yet rue having gone to court [as] sometimes it's better that it's not clarified than it is clarified ... I hope that they would ... make sure that they would implement and comply with the Labour Relations Act, and the Basic Conditions of Employment Act, much, much better now that they have decided to classify themselves as coloureds as in the past. ${ }^{88}$

In Parliament he also stated that there had been "distortion of facts and legal issues surrounding the applications made by the Chinese Association of South Africa against his ministry". 89

The Chinese Association of South Africa's legal representative in the case, George van Niekerk of Edward Nathan and Sonnenbergs, responded to the Minister's statements by pointing out that the Minister had chosen not to oppose the granting of the order and that his "comments were in conflict with the constitution and the country's statutes". Van Niekerk also said that his statements about the South African Chinese community were "factually inaccurate", while the Chinese Association of South Africa "stopped just short of saying the Minister was in contempt of court". ${ }^{90}$ Following on from this, the Chinese Association of South Africa and their legal representative referred the Minister's comments to the Human Rights Commission, saying that they amounted to "crude racial stereotypes" and complained that they were "unfair" and promoted "harmful assumptions". ${ }^{91}$

In the midst of this furor, in a letter to the editor of the Saturday Star, one reader touched on an aspect that goes to the heart of the matter: "Ignorance of history is no excuse for xenophobia." 92 Teboho Katze wrote that he failed to "understand why

86 Pheko 2008: 23.

87 Accone \& Mthethwa 2008: 13; Donaldson 2008: 2; Baleta 2008: 12.

88 SAPA 2008b: 2; Ngqiyaza 2008: 6.

89 Donnelly 2008: 16.

90 Ngqiyaza 2008a: 3; Ngqiyaza June 2008b: 6.

91 Donnelly 2008: 16. The case was never resolved as in 2010 Minister Mdladlana ended his term as Minister of Labour and took on an ambassadorial position.

92 Katze 2008: 14. Xenophobic violence had erupted in townships in Gauteng against individuals from neighboring African countries such as Mozambique, Malawi and Zimbabwe. Sixty-four people died. 
this week's verdict by the Pretoria High Court classifying South Africans of Chinese descent as black and thus previously disadvantaged caused such a stir". He stated that

[i]f anything, the condemnation highlight[s] our people's extraordinary ignorance in so far as the history is ... concerned. And if it is a question of extreme ignorance, then the government is to blame. A country that fails to support the teaching and learning of its national history ... should brace itself for such things. ${ }^{93}$

Focusing on a different issue, but coming to the same conclusion, was the rather coincidental article published during the same week by academic and educationist Rob Siebörger entitled "Don't rob our pupils of crucial lessons in history" wherein he argued that

[w]ithout a sense of history being ingrained in school, it's likely that the young adults caught up in xenophobic violence were unaware of how South Africans were received by countries around us in the past ... ${ }^{94}$

He continued by stating that

[i]n order to understand history in such a way that they can use it to inform their thinking, youths need to go into more depth, debate, weigh up and consider the impact of events and the actions of people. Future leaders in their professions and communities need these insights, and it's high school pupils who are being denied the insights by short-sighted policies of schools that elect to drop history, consign it to less able pupils, or fail to employ teachers. ${ }^{95}$

The point to be made in relation to the Chinese Broad-Based Black Economic Empowerment and Economic Equity case is that the extreme public and private "ignorance" about the South African born Chinese may be sought in the very position that history has been relegated to in the broader educational system, both at secondary and tertiary level. Moreover, the persistent binary perception of the South African past in terms of "black" and "white" has meant that "other" histories of minorities are often marginalised. ${ }^{96}$ This has indeed been the case with the Chinese who have been part of the South African past since the seventeenth century. The South African born Chinese involved in the recent High Court decision are third, fourth and fifth generation Chinese whose ancestors arrived from the end of the nineteenth century. They had nothing to do with the 63695 Chinese indentured labourers who worked on the Witwatersrand gold mines between 1904 and 1910; they were not part of the National Party scheme to attract wealthy Taiwanese entrepreneurs to rescue the

93 Ibid.

94 Siebörger 2008: 15. The teaching of history at South African schools had undergone a dramatic decline. History was taught together with geography as a social science and there was a distinct decline in the number of learners taking the subject to matric.

95 Ibid.

96 See, eg, Harris 2004. 
apartheid state's lagging economy; and they are not related to the new, or third wave, of Chinese who have converged on South Africa (both legally and illegally) from mainland China and other Pacific regions. Moreover, the South African born Chinese were never granted "honorary white status" by the apartheid architects - in fact neither were the Japanese. ${ }^{97}$

The invidious position the Chinese found themselves in is integral to the historical record: The South African born Chinese minority were indeed discriminated against. This is a view that the first president of the new democratic government, Nelson Mandela, neatly encapsulated in an address delivered in 1998 when he said they were

a community which has shared the indignities heaped on all those in South Africa who were not categorized as "white", a community which, because of its small size and its own insistence on human dignity, helped expose the twisted logic of apartheid..$^{98}$

In South Africa the legal history of the Chinese more than corroborates this view, a position that has continued to be perpetuated in the recent past with the surfacing of xenophobia and hate speech crimes. ${ }^{99}$ According to the dictum by overseas Chinese scholar Professor Wang Gung-Wu "[b]eing Chinese in China is in itself a complex problem, but being Chinese outside China has several complicating features" - and in the South African context this is indeed the case.

\section{BIBLIOGRAPHY}

Accone, D (1998) "Case of the Chinese can't be made in black or white, but only in yellow" The Sunday Independent 19 July: 12

Accone, D \& Mthethwa, B (2008) “Are our Chinese black enough for empowerment?” Sunday Times 29 June: 13

Adkins, B (2000) “Chinese shop race row grows” Eastern Province Herald 18 January: 7

Anon (1980) "The twilight people" Daily News 27 March: 8

Anon (1981) "Chinese community: No politics please” Financial Mail 10 July: 6

Anon (2000) "Fix this oversight" Eastern Province Herald 18 January: 4

Anon (2004) "South Africans still in limbo" Financial Mail 10 December: 10

Anon (2006) "From a slap in the face to an even bigger slap" Mail and Guardian 14 December: 10

Anon (2007) "Are Chinese black?" Critical thinking forum, On behalf of the Mail and Guardian and University of Johannesburg 28 July

97 Yamamoto 2007.

98 Mandela 1998. Nelson Mandela made this comment at an address held at the "Investment against Crime Seminar" hosted by the China Express in Johannesburg on 19 Aug 1998.

99 For details on the recent scourge against the Chinese on social media see Ho 2017. 


\section{KAREN L HARRIS}

Armstrong, J (1997) "The Chinese at the Cape in the Dutch East India Company period, 16521795" (unpublished paper, Slave Route Project Conference, Cape Town)

Baleta, T (2008) "Dangerous talk" Cape Times 27 June: 12

Cameron, J (2005) “Chinese laud Nedbank, Old Mutual” Citizen 28 September: 35

Cartoon (2008a) "Chinese now Black - Court” Citizen 20 June: 12

Cartoon (2008b) "Chinese word nou ere-swartes" Beeld 20 Junie: 18

Chinese Association of South Africa (2004) Mission Statement 22 May

Cliffe Dekker Incorporated (2004) "The status of South Africans of Chinese descent" (prepared for Empowerdex and the Department of Trade and Industry)

Donaldson, A (2008) “Say it loud, I'm black and confused” Sunday Times 29 June: 2

Donnelly, L (2008) "HRC to investigate Mdladlana" Mail and Guardian 27 June: 16

Ford, S (2006) “City Press fuels negative stereotypes” City Press 20 August: 24

Fourie, H (2008) "Chinese wat in SA gebore is, is ook nou 'swart" Beeld 19 Junie: 6

Gerardy, J (2008) "Wrongs of past made right" Saturday Star 21 June: 8

Harris, KL (1995) "Chinese merchants on the Rand, c 1850-1910" South African Historical J 33 November: $316-325$

Harris, KL (1996) "The Chinese, Gandhi and passive resistance" in J Brown \& M Prozesky (eds) Gandhi and South Africa: Principles and Politics (Pietermaritzburg and USA, Natal University Press and St Martin's Press): 69-94

Harris, KL (1997) "The South African Chinese: A community record of a neglected minority", South African Historical J May 36: 316-325?

Harris KL (1998a) “A history of the Chinese in South Africa to 1912” (D Litt et Phil, Unisa, Pretoria)

Harris, KL (1998b) "The Chinese in South Africa: An interstitial community" in L Wang \& G Wang (eds) The Chinese Diaspora: Selected Essays (Singapore)

Harris, KL (1999) "Accepting the group, but not the area: The Chinese and the Group Areas Act" South African Historical J May 40: 179-201

Harris, KL (2004) "Encouraged and excluded: The Chinese at the Cape a century ago" (unpublished paper, Historical Association of South Africa, Centenary Conference, University of Stellenbosch, 5-7 April)

Harris, KL (2009) “'Confusion, heaven and honour': Being Chinese in South Africa” African Historical Review 41 (2): 116-128

Harris, KL (2010a) "Anti-Sinicism: Roots in pre-industrial colonial Southern Africa" in African and Asian Studies 9 (3): 213-231

Harris, KL (2010b) "En route to 'Dignity Day': The South African Chinese and historical commemorations" Historia 55(2): 147-162

Harris, KL (2010c) "Sugar and gold: Indentured Indian and Chinese labour in South Africa" J of Social Sciences (Special Volume) 11: 147-158

Ho, U (2008) “Chinese locals are black” Business Report 19 June: 1

Ho, U (2017) "Hate speech is blind ignorance" The Times 14 February: 13

Holmes, C (2000) “Chinese forgotten by everyone” Eastern Province Herald 7 November: 4 
Jacks, M (2005) “Chinese get BEE status” Financial Mail 30 September: 69

Jeffries, KM \& Naude SD (eds) (1948) Kaapse Argiefstukke: Kaapse Plakkaatboek, Deel 2, 1707 1753 (Kaapstad, Cape Times, 1948)

Katze, T (2008) "Ignorance of history is no excuse for xenophobia" Saturday Star 21 June: 14

MacKenzie, C (2008) "Taiwanese get a second bite of the cherry in farcical BEE" Star 26 June: 20

Mandela, N (1998) Address at the Investment against Crime Seminar hosted by the China Express

19 August 1998 (accessed June 2016) available at http://www.mandela.gov.za/mandela speeches/1998/980819_crime.htm

Masombuka, S (2008) "SA Chinese now qualify for BEE” Sowetan 19 June: 4

Mativire, M (2000) "Council to review land sales policy” Eastern Province Herald 29 January: 6

Mativire, M (2000) “Chinese won’t benefit from land policy” Eastern Province Herald 8 March: 4

Ndlovu, V (2008) "Chinese not black" The Sowetan 20 June: 4

Ngqiyaza, B (2008a) “Anti-Chinese comments ignite row” Pretoria News 26 June: 3

Ngqiyaza, B (2008b) “Mdladlana blasted over 'insulting' remarks on Chinese” The Star 26 June: 6

Nwajah, O (2000) "Overcoming qualified citizenship" Mail and Guardian 29 September: 16

Pheko, M (2008) "Black judgment subjects Chinese to animosity, not equality" Sunday Times 23 June: 23

Robins, M (1997) "Flash back" Cape Argus 10 February: 8

Rossouw, M (2005) "Nedbank en Ou Mutual sluit Chinese in by bemagtiging” Beeld 28 September: 20

Rossouw, R (2008) “Chinese South Africans entitled to redress” The Weekender 5 July: 6

Sakato, T (2005) "Race classification causes confusion” Weekly Mail and Guardian 30 June: 6

SAPA (2008a) "Chinese qualify for BEE, court rules" The Pretoria News 19 June: 4

SAPA (2008b) "Labour Minister rockets Chinese" The Star 25 June: 2

SAPA (2008c) "SA's Chinese qualify for BEE deals, court rules" The Star 19 June: 5

Siebörger, R (2008) “Don’t rob our pupils of crucial lessons in history” Pretoria News 19 June: 15

Sundstrom, K \& Van der Merwe, J (2000) "SA Chinese not black enough" Saturday Argus 23 January: 10

Terblanche, B (2006) "Chinese fight to be black" Mail and Guardian 14 December: 10

The Chinese Association - Gauteng: Newsletters 2000, 2002

Whyte, V (2005a) "Beeing Chinese" Financial Mail 21 October: 11

Whyte, V (2005b) “Too ‘yellow' to gain from BEE?” Business Day 30 November: 14

Wilkins, I (1981) “At last the dragon stirs" Sunday Times 14 June: 31

Yamamoto, L (2007) "Honorary or honorable? A study of Japanese residents in South Africa during the apartheid era with special reference to their experiences and their understanding of their status in the white-dominant society" (MA dissertation, University of Cape Town)

Yap, M \& Man, D (1996) Colour, Confusion and Concessions: The History of the Chinese in South Africa (Hong Kong) 


\section{Legislation}

Codex van Den Locale Wetten ZAR Wet no 31885

De Locale Wetten en Volksraad Besluiten der ZAR 1893

The Chinese Exclusion Act no 37 of 1904

Asiatic Law Amendment Act no 2 of 1907

The Immigration Amendment Act no 19 of 1933

Population Registration Act no 30 of 1950

Proclamation no 73 March 1951

Proclamation no 46 March 1959

Republic Amendment Act no 53 of 1986

Employment Equity Act 55 of 1998

Broad-Based Black Economic Empowerment Act 53 of 2003

\section{Court cases}

Chinese Association of South Africa v Minister of Labour (59251/2007) [2008] ZAGPHC 174 (18 Jun 2008). Notice of Motion: case no 59251/07, High Court of South Africa (TPD) Pretoria 18 Jun 2008

Chinese Association of South Africa v Minister of Labour (59251/2007) [2008] ZAGPHC 174 (18 Jun 2008) Second Applicant's founding affidavit: V Chong, pp 1-17, case no 59251/07, High Court of South Africa (TPD) Pretoria 18 Jun 2008

Chinese Association of South Africa v Minister of Labour (59251/2007) [2008] ZAGPHC 174 (18 Jun 2008) Second Applicant's founding affidavit: AP Fung, pp 1-12, case no 59251/07, High Court of South Africa (TPD) Pretoria 18 Jun 2008

Chinese Association of South Africa v Minister of Labour (59251/2007) [2008] ZAGPHC 174 (18 Jun 2008) Second Applicant's founding affidavit: LH Hoy pp 1-9, case no 59251/07, High Court of South Africa (TPD) Pretoria 18 June 2008

Chinese Association of South Africa v Minister of Labour (59251/2007) [2008] ZAGPHC 174 (18 Jun 2008) Second Applicant's founding affidavit: M Yap pp 1-12 and DL Man, pp 1-5, case no 59251/07, High Court of South Africa (TPD) Pretoria 18 Jun 2008

Chinese Association of South Africa v Minister of Labour (59251/2007) [2008] ZAGPHC 174 (18 Jun 2008) Second Applicant's founding affidavit: KL Harris, pp 1-12, case no 59251/07, High Court of South Africa (TPD) Pretoria 18 Jun 2008

Chinese Association of South Africa v Minister of Labour (59251/2007) [2008] ZAGPHC 174 (18 Jun 2008) "Chinese Association of South Africa: chronological timeline" 2008 